\title{
George Simpson (ca. 1787-1860)
}

Sir George Simpson, overseas Governor-in-Chief of the Hudson's Bay Company, is remembered chiefly for his success in integrating the field operations of the rival Hudson's Bay and North West Companies after their union in 1821. No explorer himself, he assisted, albeit reluctantly, John Franklin's first sortie into the Arctic and, more willingly, subsequent Admiralty expeditions. He was also responsible for organizing Company-mounted explorations and searches in the North.

Simpson was born about 1787 in Loch Broom Parish, Scotland, of unmarried parents. Little is known of his early life, but by 1800 or soon after he was employed in the London firm of his uncle, Geddes Simpson, engaged in the sugar trade.

The little red-headed Scot was physically unimpressive, but grew up with a vast thirst for success and renown, perhaps in reaction to his small stature and illegitimate birth. Ruthless and insensitive in business, he made many enemies, but through his unswerving loyalty to his friends he gained some equally firm admirers. He became as notorious for his amorous exploits as he was famous for his commercial achievements. After ten years with and a brood by a "country wife", he married his cousin Frances Simpson and sired another family. In addition, he begat an indefinite number of off-the-record progeny. Today his direct descendants can be found in many parts of Canada.

Although Simpson himself was completely ignorant of the fur trade, the Honorable Company, in which his uncle's partner Andrew Wedderburn had an interest, sent him to America. He was to serve as replacement for Governor William Williams, whose imminent arrest by the Nor'Westers was anticipated. When Williams escaped apprehension, the Company sent Simpson to Fort Wedderburn, on Lake Athabasca, to take charge of the Athabasca Department. So successful was he during 1820-21 in confronting the aggressive, even violent opposition headquartered in nearby Fort Chipewyan, that when the two companies were amalgamated in 1821, Simpson was appointed Governor of the Hudson's Bay Company's Northern Department.

It was while he was at Fort Wedderburn that Simpson had his first, albeit indirect, contact with the Arctic, for during his tenure there, John Franklin passed that way on his first arctic land expedition. His party seemed inordinately intimate with the rival Nor'Westers, yet made what Simpson regarded as unreasonable and excessive demands on the resources of the older company.

Simpson had spent the winter of 1820-21 in the North, although as Governor of the Northern and soon of the Southern Department of the Company and from 1827 as Governor-in-Chief, his principal residence was briefly at Upper or Lower Fort Garry, later at Lachine. But almost every year until his death he journeyed to the distant reaches of the Company's realms. In 1822, 1823, and 1824 he returned to Lake Athabasca, sometimes even reaching Great Slave Lake.

Simpson's concern with the Arctic was that of his employers; they regarded it primarily as a source of furs and profits. Yet in the early 1800 s, the Company's very existence was endangered through attacks on its splendid Charter by which Charles II had granted it possession of a quarter of North America and exclusive trading rights therein. In return, the Company was to promote settlement, civilization, and exploration in its territory, obligations which it was slow to meet. True, it had mounted a few exploring expeditions, abortive and sometimes fatal, in Hudson Bay, but they were long ago. To meet persistent criticism, in 1838 the Governor sent young Thomas Simpson and experienced Peter Warren Dease to complete the mapping of the arctic coast. Their three-year odyssey resulted in surveys of hundreds of miles of coastline, and a knighthood for Governor Simpson. A planned second expedition under Thomas Simpson was prevented by the young man's untimely and violent death.

In 1844 , Simpson chose a Company clerk, Dr. John Rae, to head another sortie to the Frozen Ocean. In 1846 Rae led a small party to brilliant exploring success in the northeast corner of the continent. In an 1854 Company-organized foray, Rae discovered the first relics of the lost Franklin expedition.

Throughout the long search for Franklin, the Company - under Simpson's direction - assisted such Admiralty expeditions as Dr. John Richardson's with material and personnel, and mounted its own searches, such as James Anderson's 1855 journey. All, of course, were futile. Not until 1859 did Francis McClintock discover definitive evidence of Franklin's fate.

Simpson died in Montreal a few days after hosting an elaborate reception at Lachine for the visiting Prince of Wales.

\section{FURTHER READINGS}

GALBRAITH, JOHN S. 1976. The Little Emperor: Governor Simpson of the Hudson's Bay Company. Toronto: Macmillan.

MERK, F. (ed.). 1931. Fur Trade and Empire: George Simpson's Journal 1924-25. Cambridge: Harvard University Press.

MORTON, A.S. 1944. Sir George Simpson: Overseas Governor in the Hudson's Bay Company. Toronto: J.M. Dent.

RICH, E.E. (ed.). 1938. Simpson's Athabasca Journal. Toronto: Champlain Society.

(ed.). 1947. Simpson's 1828 Journey to the Columbia. London: Champlain Society.

John W. Chalmers

8128 - 97 Avenue

Edmonton, Alberta, Canada

T6C 2B7 


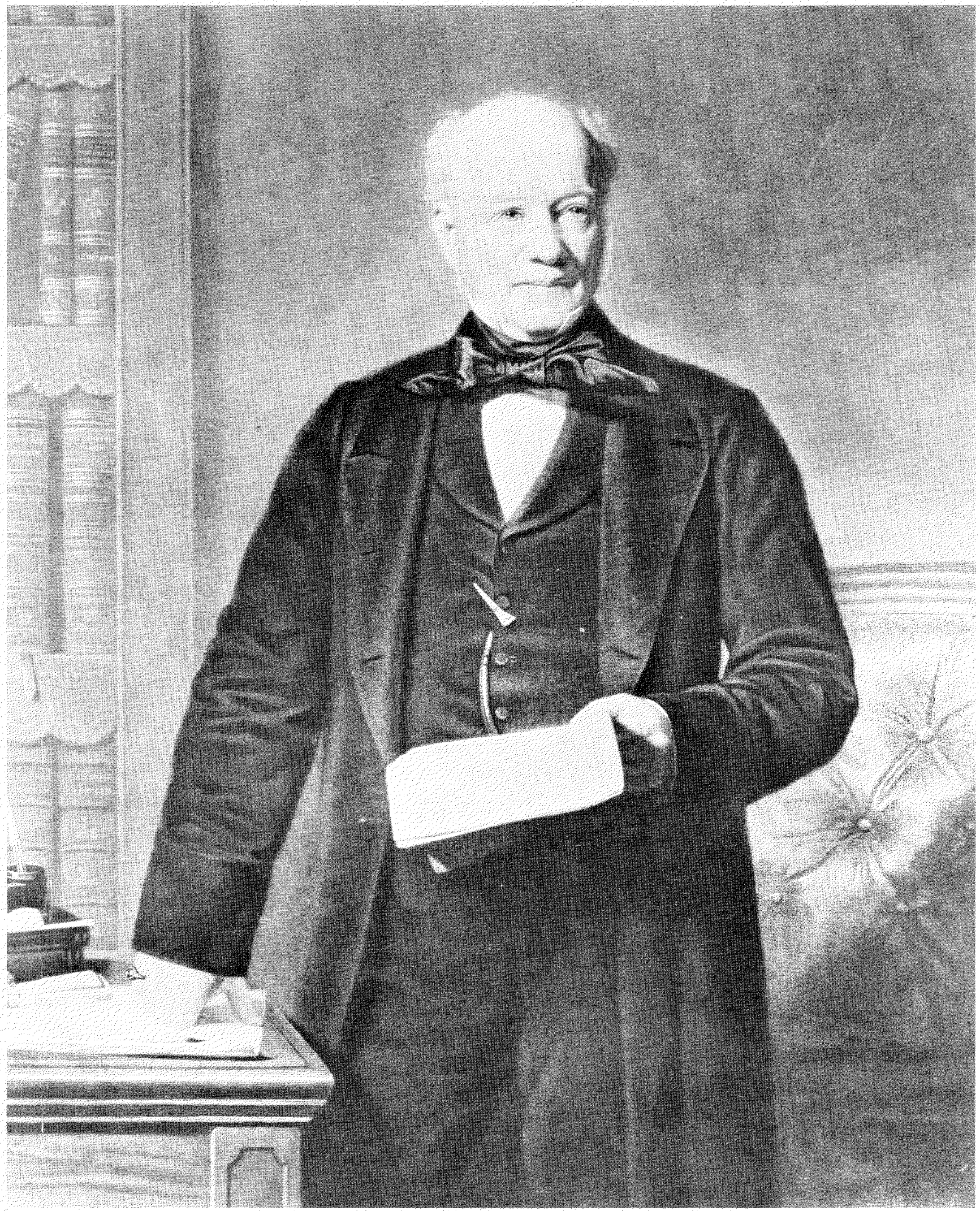

The Public Archives of Canada 